\title{
Liquid-Liquid Equilibrium Phase Diagrams of New Aqueous Two-Phase Systems: Ucon 50-HB5100 + Ammonium Sulfate + Water, Ucon 50-HB5100 + Poly(vinyl alcohol) + Water, Ucon 50-HB5100 + Hydroxypropyl Starch + Water, and Poly(ethylene glycol) $\mathbf{8 0 0 0}+$ Poly(vinyl alcohol) + Water
}

\author{
Martinha Pereira, ${ }^{\dagger}$ You-Ting Wu, ${ }^{\dagger}$ Pedro Madeira, ${ }^{\dagger,}{ }^{\ddagger}$ Armando Venâncio, ${ }^{\dagger}$ E ugénia Macedo, ${ }^{\ddagger}$ and \\ J osé Teixeira*,t
}

Centro de Engenharia Biológica-I BQF, Universidade do Minho, 4710-057 Braga, Portugal, and LSRE Laboratory of Separation and Reaction Engineering, Departamento de Engenharia Química, Faculdade de Engenharia, Universidade do Porto, Rua Dr. Roberto Frias, 4200-465 Porto, Portugal

\begin{abstract}
The phase diagrams of Ucon 50-HB-5100 (Ucon) + ammonium sulfate $\left(\mathrm{NH}_{4}\right)_{2} \mathrm{SO}_{4}+$ water, $\mathrm{U}$ con $50-\mathrm{HB}$ 5100 + poly(vinyl al cohol) 10000 (PVA 10000) + water, U con 50-HB-5100 + hydroxypropyl starch (Reppal PES 100) + water, and poly(ethylene glycol) 8000 (PEG 8000)-PVA 10000 systems were determined at $22{ }^{\circ} \mathrm{C}$. Measurements at 30 and $40^{\circ} \mathrm{C}$ were also done for each U con-salt system. A linear regression was used to calculate the slope and standard deviation for each tie line. The standard deviations are in most situations lower than 0.1 , and the tieline slopes for each phase diagram vary within $5.5 \%$ around the medium value for all cases with the exception of the $\mathrm{U}$ con $+\left(\mathrm{NH}_{4}\right)_{2} \mathrm{SO}_{4}+$ water system at $40{ }^{\circ} \mathrm{C}$. The phase diagrams of the $\mathrm{Ucon}+\left(\mathrm{NH}_{4}\right)_{2} \mathrm{SO}_{4}+$ water system at different temperatures were shown to have a smaller amount of salt and polymer than conventional systems and to be thermoseparating, versatile, and particularly attractive, since phase formation is temperature-dependent. The phase diagrams of $U$ con + PVA 10000 + water, Ucon + PES + water, and PEG + PVA 10000 + water systems were very similar, since high polymer concentrations (PES or PVA 10000) are required to form the two phases.
\end{abstract}

\section{Introduction}

Aqueous two-phase systems (ATPS) were for the first time reported by Beijernick ${ }^{1}$ when he found that a mixture of gelatine and starch could form two phases. Albertsson and co-workers reinvestigated and studied the ATPS thoroughly and developed several applications in the field of separation. ${ }^{2}$ Since then many researchers have been devoted to the study of ATPS and their applications. There exist three classes of aqueous two-phase systems: polymer + polymer + water, polymer + salt + water, and thermoseparating systems.

The polymer + salt + water systems are most widely used for large-scale and laboratory-scal e extraction..$^{3-5}$ The protein partitioning in poly(ethylene glycol) (PEG) + salt + water systems is partly an effect of salting out of the protein from one of the phases.

Aqueous solutions of a thermoseparating polymer can form an aqueous two-phase system when incubated above the lower critical solution temperature (LCST). EOPO (ethylene oxide + propylene oxide) copolymers are such a kind of thermoseparating polymers that form a relatively concentrated polymer phase and a water phase at temperatures above the LCST. The water phase contains a larger number of molecules than the polymer enriched phase. Biomolecules prefer the phase having more molecules for entropic reasons. ${ }^{6}$ The EOPO + water system is more suitable for the partitioning of amino acids and peptides

* To whom correspondence should be addressed. Phone: +351 253 604400. Fax: +351 253 678986. E-mail: jateixeira@deb.uminho.pt. + Universidade do Minho.

₹ Universidade do Porto. than of proteins. ${ }^{7}$ For the purification of proteins, the hydrophobically modified EOPO polymer can be used, ${ }^{8}$ since this polymer forms a less concentrated phase after separation.

Of the two-polymer systems, the PEG + dextran + water system ${ }^{9,10}$ has been more thoroughly studied, and it has been extensively used to characterize the partition mechanisms of biomolecules ${ }^{9,11}$ and purify biomaterials on the laboratory scale. Another two-polymer system, PEG + starch + water, was widely used in large-scale applications. ${ }^{12}$ Starch derivatives such as hydroxypropyl starch have been shown to be suitable substitutes for dextran. ${ }^{13-15}$ The results obtained for these two types of systems were similar, but the starch derivatives have the advantage of decreasing the cost of the bottom phase polymer.

Random copolymers of ethylene oxide (EO) and propylene oxide (PO) can be used as substitutes for PEG. The advantage of using EOPO copolymers is that the polymer can be easily recovered after use due to the thermoseparating properties. ${ }^{16-18}$ When introducing these EOPO copolymers into the conventional polymer + polymer + water or polymer + salt + water systems, a large amount of hybrid ATPS can be generated. These hybrid systems are of more attractive characteristics than the traditional ones when being used in separation processes. We are focusing most of our attention on these systems.

In this work, Ucon 50-HB-5100, an EOPO random copolymer of $50 \%$ ethylene oxide and $50 \%$ propylene oxide (mass) with an average molecular weight of $3900\left(M_{r}\right)$, was selected as one of the phase-forming substances to form ATPS with $\left(\mathrm{NH}_{4}\right)_{2} \mathrm{SO}_{4}$, poly(vinyl alcohol) (PVA 10000), or 
Table 1. Phase Compositions, Plait Points, Tie-Line Slopes, Standard Deviation $(\sigma)$, and the Medium of the Tie-Line Slopes of the Ucon 50-HB5100 $\left(\mathrm{M}_{\mathrm{r}}=3900\right)\left(w_{1}\right)+\left(\mathbf{N H}_{4}\right)_{2} \mathrm{SO}_{4}\left(w_{2}\right)+$ Water $\left(w_{3}\right)$ Two-Phase Systems at Three Temperatures

\begin{tabular}{|c|c|c|c|c|c|c|c|c|}
\hline \multicolumn{2}{|c|}{ total compositions } & \multicolumn{2}{|c|}{ top phase } & \multicolumn{2}{|c|}{ bottom phase } & \multirow[b]{2}{*}{ slope } & \multirow[b]{2}{*}{$\sigma$} & \multirow[b]{2}{*}{ medium } \\
\hline $100 w_{1}$ & $100 w_{2}$ & $100 w_{1}$ & $100 w_{2}$ & $100 w_{1}$ & $100 w_{2}$ & & & \\
\hline $\begin{array}{l}10.01 \\
16.14 \\
16.96 \\
18.91 \\
\text { plait point }\end{array}$ & $\begin{array}{l}6.55 \\
5.80 \\
6.20 \\
6.98\end{array}$ & $\begin{array}{l}26.52 \\
30.72 \\
34.72 \\
39.67 \\
10.80\end{array}$ & $\begin{array}{l}3.04 \\
2.56 \\
2.14 \\
1.68 \\
5.32\end{array}$ & $\begin{aligned} & \mathrm{t}= 22^{\circ} \mathrm{C} \\
& 2.06 \\
& 1.34 \\
& 0.91 \\
& 0.38\end{aligned}$ & $\begin{array}{r}8.45 \\
9.36 \\
10.20 \\
11.81\end{array}$ & $\begin{array}{l}-4.54 \\
-4.32 \\
-4.20 \\
-3.88\end{array}$ & $\begin{array}{l}0.133 \\
0.099 \\
0.104 \\
0.023\end{array}$ & $\begin{array}{l}-4.24 \\
\pm 0.24\end{array}$ \\
\hline $\begin{array}{l}12.03 \\
12.06 \\
12.05 \\
12.03 \\
\text { plait point }\end{array}$ & $\begin{array}{l}4.00 \\
4.50 \\
5.00 \\
5.52\end{array}$ & $\begin{array}{r}6.08 \\
2.89 \\
1.96 \\
1.30 \\
11.80\end{array}$ & $\begin{array}{l}4.94 \\
6.04 \\
6.72 \\
7.43 \\
3.77 \\
\end{array}$ & $\begin{array}{c}\mathrm{t}=30^{\circ} \mathrm{C} \\
19.66 \\
27.00 \\
31.51 \\
34.96\end{array}$ & $\begin{array}{l}2.88 \\
2.22 \\
1.84 \\
1.56\end{array}$ & $\begin{array}{l}-6.60 \\
-6.33 \\
-6.07 \\
-5.74\end{array}$ & $\begin{array}{l}0.138 \\
0.164 \\
0.075 \\
0.042\end{array}$ & $\begin{array}{l}-6.19 \\
\pm 0.32\end{array}$ \\
\hline $\begin{array}{l}10.09 \\
10.00 \\
9.95 \\
10.02 \\
\text { plait point }\end{array}$ & $\begin{array}{l}2.57 \\
3.50 \\
4.47 \\
5.51\end{array}$ & $\begin{array}{r}4.94 \\
1.92 \\
1.05 \\
0.60 \\
14.00\end{array}$ & $\begin{array}{l}3.09 \\
4.30 \\
5.50 \\
6.82 \\
1.86\end{array}$ & $\begin{array}{c}\mathrm{t}=40^{\circ} \mathrm{C} \\
27.72 \\
38.41 \\
45.73 \\
51.03\end{array}$ & $\begin{array}{l}1.24 \\
0.95 \\
0.76 \\
0.63\end{array}$ & $\begin{array}{r}-12.50 \\
-10.95 \\
-9.48 \\
-8.22\end{array}$ & $\begin{array}{l}0.735 \\
0.200 \\
0.178 \\
0.210\end{array}$ & $\begin{array}{r}-10.29 \\
\pm 1.60\end{array}$ \\
\hline
\end{tabular}

hydroxypropyl starch (Reppal PES100) as another phaseforming species. The phase diagrams of these theromoseparating $U$ con-based systems together with the poly(ethylene glycol) (PEG 8000) + PVA 10000 + water system are presented in this paper.

\section{Materials and Methods}

Chemicals. U con 50-HB-5100 (U con), a random copolymer (with average molecular weight $M_{r}=3900$ ) of $50 \%$ ethylene oxide and $50 \%$ propylene oxide, was obtained from Union Carbide (NY), poly(vinyl alcohol) (PVA 10000, $\mathrm{M}_{\mathrm{r}}=$ 10 000, 88\% hydrolyzed) from Scientific Polymer Products (NY), and hydroxypropyl starch (Reppal PES100, $\mathrm{M}_{\mathrm{r}}=$ 100 000) from REPPE AB (Sweden). Other chemicals are of analytical reagent grade. All polymer and salt concentrations are given as mass fractions.

Aqueous stock solutions of PEG (PEG mass fraction $=$ 0.4), salt (salt mass fraction $=0.4$ ), PVA 10000 (PVA 10000 mass fraction $=0.3$ ), and Reppal PES 100 (PES 100 mass fraction $=0.4$ ) were prepared, respectively, prior to the use in ATPS.

Aqueous Two-Phase Systems. The systems were prepared by adding appropriate masses of the phase-forming substances (pure U con or PEG stock solution as one phaseforming species, salt, PVA 10000 or Reppal PES 100 stock solution as another one) into a tube. Water was finally added to make a $10 \mathrm{~g}$ system for the U con-salt system or a $15 \mathrm{~g}$ system for the systems U con + PES100 + water and U con + PVA + water. After that, the systems were vigorously mixed to become turbid and then placed overnight ( $\geq 12 \mathrm{~h}$ ) in a temperature controlled bath (B. Braun, Frigomix $\mathrm{S}$ with an uncertainty of $\pm 0.1^{\circ} \mathrm{C}$ ) at the required temperature. The top and bottom phases were collected for characterization.

Phase Diagram Determination. A phase diagram is constituted by a binodal curve and tie lines. The binodal curve represents the borderline between the one-phase and two-phase regions. The tie line describes the compositions of the two phases in equilibrium. The tie-line length (TLL) is defined as

$$
T L L=\sqrt{\left(w_{1}^{\top}-w_{1}^{B}\right)^{2}+\left(w_{2}^{\top}-w_{2}^{B}\right)^{2}}
$$

where $w_{i}^{\top}$ and $w_{i}^{B}$ represent the mass fractions of phaseforming component $i$ in top and bottom phases, respec- tively. The plait points were obtained by connecting the midpoints of tie lines and then extrapolating this midpoint curve to the binodal.

The phase diagram of $U$ con $+\left(\mathrm{NH}_{4}\right)_{2} \mathrm{SO}_{4}+$ water was determined by titrimetry and refractive index measurements of the phases. The refractive index method was used to determine the total concentrations of U con and $\left(\mathrm{NH}_{4}\right)_{2-}$ $\mathrm{SO}_{4}$ in the top and bottom phases, respectively. Standard curves (mass fraction up to 0.05) for the refractive index of $\mathrm{U}$ con and $\left(\mathrm{NH}_{4}\right)_{2} \mathrm{SO}_{4}$ were determined respectively using a refractometer 3T (Atago-J apan). The determination was done at $25^{\circ} \mathrm{C}$ in a temperature controlled bath (B. Braun, Frigomix S with an uncertainty of $\pm 0.1{ }^{\circ} \mathrm{C}$ ). Since the refractive index of a polymer and salt solution at a low total mass fraction (i.e., <0.10) is additive, ${ }^{9}$ a proper dilution (usually 3- to 5-fold) of the phases is necessary to determine the refractive index. Since the concentration of $\left(\mathrm{NH}_{4}\right)_{2} \mathrm{SO}_{4}$ can be measured accurately, the copolymer concentration can be calculated by determining the refractive index of a phase at $25{ }^{\circ} \mathrm{C}$ and subtracting the contribution of salt. The formaldehyde reaction mechanism ${ }^{19,20}$ was used to measure the $\left(\mathrm{NH}_{4}\right)_{2} \mathrm{SO}_{4}$ concentration,

$$
\begin{aligned}
2\left(\mathrm{NH}_{4}\right)_{2} \mathrm{SO}_{4}+6 \mathrm{HCHO} & = \\
& \mathrm{N}_{4}\left(\mathrm{CH}_{2}\right)_{6}+2 \mathrm{H}_{2} \mathrm{SO}_{4}+6 \mathrm{H}_{2} \mathrm{O}
\end{aligned}
$$

A $0.1 \mathrm{M}$ standardized $\mathrm{NaOH}$ solution was used to titrate the sulfuric acid produced, using phenolphthalein as indicator. The analysis showed that the presence of copolymer did not interfere with the determination, and the accuracy of the titration was within $0.4 \%$. A tie line measured by this methodology was also verified by using a combination of freeze-drying and refractive index measurements. The latter methodology has been widely used in the literature ${ }^{9,21}$ and was adopted for the determination of Ucon + PVA 10000 + water, Ucon + PES100 + water, and PEG + PVA 10000 + water phase diagrams in this study. Using the system's overall mass balance and a calibration equation for the refractive index, a set of two equations was obtained and allowed the determination of the polymers' concentrations. All mass measurements were done in a balance from Adam Equipment Co, Lda (ADA 180) with $a \pm 0.1 \mathrm{mg}$ uncertainty. The uncertainties of the mass fractions of the polymers and $\left(\mathrm{NH}_{4}\right)_{2} \mathrm{SO}_{4}$ were 0.001 for $\mathrm{U}$ con $+\left(\mathrm{NH}_{4}\right)_{2} \mathrm{SO}_{4}+$ water systems and 0.004 for the 


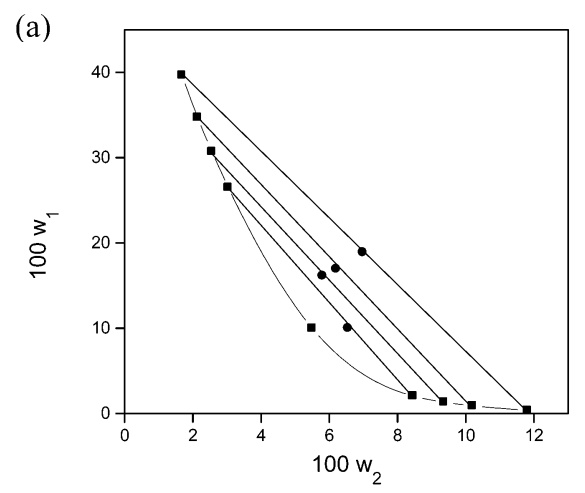

(b)

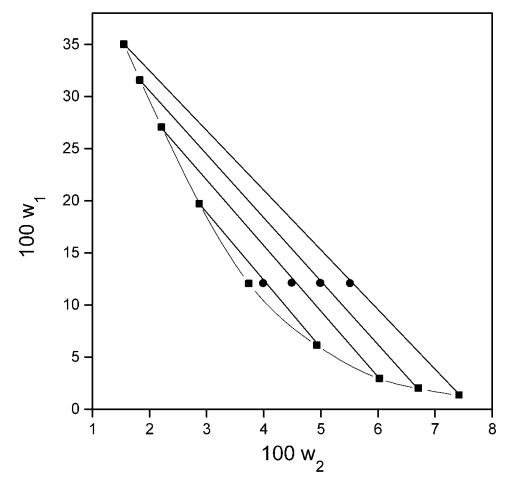

(c)

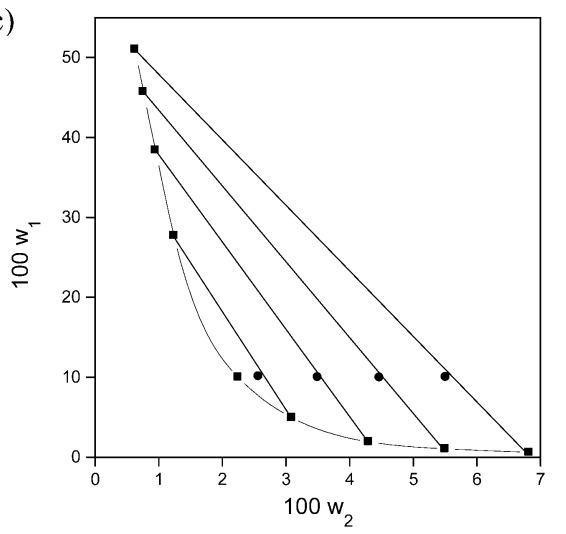

Figure 1. Phases diagrams of the Ucon $+\left(\mathrm{NH}_{4}\right)_{2} \mathrm{SO}_{4}+$ water system: (a) $22{ }^{\circ} \mathrm{C}$; (b) $30{ }^{\circ} \mathrm{C}$; (c) $40{ }^{\circ} \mathrm{C}$; (回) binodal; (•) total composition.

three polymer + polymer + water systems. For each concentration, the experiments were done in duplicate.

\section{Results and Discussion}

Ucon $+\left(\mathbf{N H}_{4}\right)_{2} \mathbf{S O}_{4}+$ Water ATPS. The liquid-liquid equilibrium data of the $U$ con- $\left(\mathrm{NH}_{4}\right)_{2} \mathrm{SO}_{4}$ system at 22,30 , and $40^{\circ} \mathrm{C}$ were given in Table 1 , as well as the plait points and the tie-line slopes (regression was made for each tie line). Figure 1 showed the phase diagrams, Figure 2 presented the binodals at different temperatures, and Figure 3 presented the comparison of the phase diagram of the $\mathrm{U}$ con $+\left(\mathrm{NH}_{4}\right)_{2} \mathrm{SO}_{4}+$ water system at $22{ }^{\circ} \mathrm{C}$ with that of the EOPO $4000+\left(\mathrm{NH}_{4}\right)_{2} \mathrm{SO}_{4}+$ water system at 25 ${ }^{\circ} \mathrm{C} .{ }^{22}$

It was found that the standard deviation of the tie-line slopes at 22 and $30{ }^{\circ} \mathrm{C}$ is around 0.1 (see Table 1). The system at $40^{\circ} \mathrm{C}$ presents a standard deviation of about 0.2 for three tie lines and 0.7 for one tie line. In addition, increasing the temperature decreases the medium value of the slopes, indicating the increasing of the asymmetry of the diagrams.

As shown in Figure 2, the higher the temperature, the lower the polymer and salt concentrations for the formation

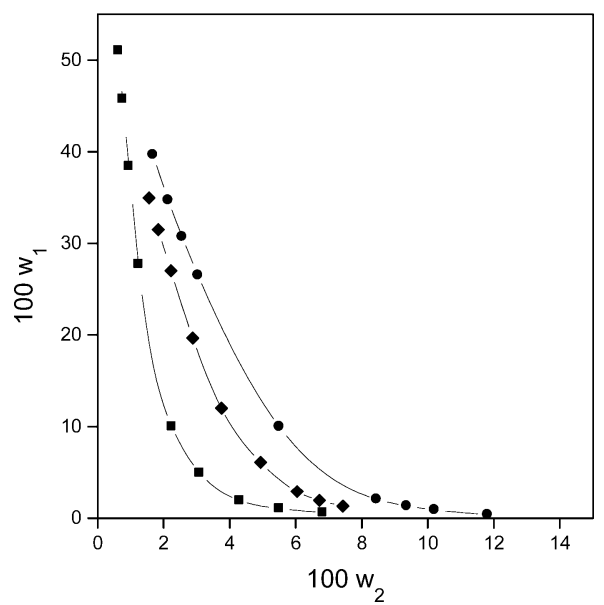

Figure 2. Binodals for the phase diagrams of the $U$ con $+\left(\mathrm{NH}_{4}\right)_{2-}$ $\mathrm{SO}_{4}+$ water system at $22^{\circ} \mathrm{C}(\mathbf{O}), 30^{\circ} \mathrm{C}(\bullet)$, and $40{ }^{\circ} \mathrm{C}(\boldsymbol{\square})$.

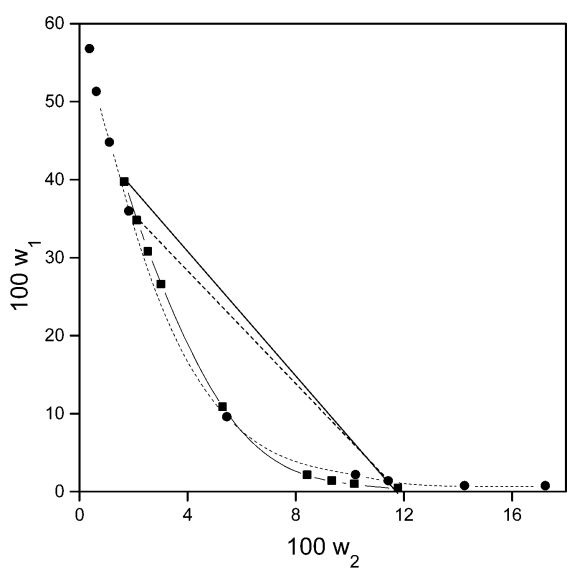

Figure 3. Binodal ( $\square$ ) and tie line (-) for the system Ucon + $\left(\mathrm{NH}_{4}\right)_{2} \mathrm{SO}_{4}+$ water at $22{ }^{\circ} \mathrm{C}$. Binodal $(\bullet)$ and tie line (- - -) for the EOPO $4000+\left(\mathrm{NH}_{4}\right)_{2} \mathrm{SO}_{4}+$ water system at $25^{\circ} \mathrm{C} .22$

of two phases. The salt concentration in the salt rich phase can sharply decrease to about $0.3 \mathrm{M}$ for the phase diagram at $40{ }^{\circ} \mathrm{C}$. From the comparison in Figure 3 , it was found that the binodal of the $\mathrm{U}$ con $+\left(\mathrm{NH}_{4}\right)_{2} \mathrm{SO}_{4}+$ water system at $22{ }^{\circ} \mathrm{C}$ was very close to that of EOPO $4000+\left(\mathrm{NH}_{4}\right)_{2} \mathrm{SO}_{4}$ + water at $25{ }^{\circ} \mathrm{C},{ }^{22}$ indicating that the small differences in the copolymers and temperatures had a negligible influence on the binodal. However, the tie lines for these two systems showed differences in the top phase compositions.

This new aqueous two-phase system is similar to the well-known poly(ethylene glycol) + salt + water systems most frequently used. However, if the polymer molecular weights and temperatures of the systems are kept the same, only about half of the salt concentration is required for the formation of two phases for this new system, which benefits the process economics. For example, for the formation of two phases with equal volumes, the minimum salt mass fraction required for PEG $4000+\left(\mathrm{NH}_{4}\right)_{2} \mathrm{SO}_{4}+$ water ATPS at $20^{\circ} \mathrm{C}^{9}$ is about 0.1 , and it is only 0.05 for this new system.

In addition, since $U$ con is a random copolymer of ethylene oxide and propylene oxide, it shows characteristics of thermoseparating with water when temperature increases to $47{ }^{\circ} \mathrm{C}$. These characteristics can also be used for the recycling of this copolymer from the polymer rich phase. In general, this new phase diagram has the characteristics of low salt concentration, thermoseparating polymer, and phase inversion at higher operation temperatures $\left(30^{\circ} \mathrm{C}\right.$ 
Table 2. Phase Compositions, Plait Point, Tie-Line Slopes, Standard Deviation $(\sigma)$, and the Medium of the Tie-Line Slopes of Ucon 50-HB5100 $\left(M_{r}=3900\right)\left(w_{1}\right)+$ Poly(vinyl alcohol) $10000\left(\right.$ PVA 10000) $\left(w_{2}\right)+W$ Water $\left(w_{3}\right)$ Two-Phase Systems at $22{ }^{\circ} \mathrm{C}$

\begin{tabular}{|c|c|c|c|c|c|c|c|c|}
\hline \multicolumn{2}{|c|}{ total compositions } & \multicolumn{2}{|c|}{ top phase } & \multicolumn{2}{|c|}{ bottom phase } & \multirow[b]{2}{*}{ slope } & \multirow[b]{2}{*}{$\sigma$} & \multirow[b]{2}{*}{ medium } \\
\hline $100 w_{1}$ & $100 w_{2}$ & $100 w_{1}$ & $100 w_{2}$ & $100 w_{1}$ & $100 w_{2}$ & & & \\
\hline 10.47 & 9.95 & 12.73 & 6.50 & 2.14 & 19.59 & -0.82 & 0.044 & \\
\hline 13.23 & 10.65 & 19.31 & 2.79 & 1.74 & 24.51 & -0.81 & 0.014 & -0.81 \\
\hline 11.04 & 10.97 & 16.17 & 4.13 & 1.80 & 21.78 & -0.82 & 0.028 & \pm 0.02 \\
\hline 13.27 & 11.80 & 20.67 & 2.23 & 1.68 & 27.03 & -0.77 & 0.003 & \\
\hline plait point & & 6.00 & 13.00 & & & & & \\
\hline
\end{tabular}

Table 3. Phase Compositions, Plait Point, Tie-Line Slopes, Standard Deviation $(\sigma)$, and the Medium of the Tie-Line Slope of Ucon 50-HB5100 $\left(M_{r}=3900\right)\left(w_{1}\right)+$ Hydroxypropyl Starch (PES 100) $\left(w_{2}\right)$ + Water $\left(w_{3}\right)$ Two-Phase Systems at 22 ${ }^{\circ} \mathbf{C}$

\begin{tabular}{|c|c|c|c|c|c|c|c|c|}
\hline \multicolumn{2}{|c|}{ total compositions } & \multicolumn{2}{|c|}{ top phase } & \multicolumn{2}{|c|}{ bottom phase } & \multirow[b]{2}{*}{ slope } & \multirow[b]{2}{*}{$\sigma$} & \multirow[b]{2}{*}{ medium } \\
\hline $100 w_{1}$ & $100 w_{2}$ & $100 w_{1}$ & $100 w_{2}$ & $100 w_{1}$ & $100 w_{2}$ & & & \\
\hline 4.73 & 12.08 & 5.99 & 8.84 & 2.36 & 16.73 & -0.46 & 0.033 & \\
\hline 8.04 & 12.94 & 12.36 & 3.50 & 1.75 & 26.03 & -0.47 & 0.006 & -0.46 \\
\hline 6.27 & 13.41 & 9.46 & 5.87 & 1.93 & 23.03 & -0.44 & 0.079 & \pm 0.01 \\
\hline 7.09 & 13.92 & 11.42 & 4.27 & 1.8 & 25.07 & -0.46 & 0.007 & \\
\hline 4.50 & 15.02 & 8.22 & 6.76 & 2.07 & 19.92 & -0.47 & 0.012 & \\
\hline plait point & & 3.69 & 12.30 & & & & & \\
\hline
\end{tabular}

Table 4. Phase Compositions, Plait Point, Tie-Line Slopes, Standard Deviation $(\sigma)$, and the Medium of the Tie-Line Slopes of PE G $8000\left(w_{1}\right)+$ Poly(vinyl alcohol) 10000 (PVA 10000) $\left(w_{2}\right)+$ Water $\left(w_{3}\right)$ Two-Phase Systems at $22{ }^{\circ} \mathrm{C}$

\begin{tabular}{|c|c|c|c|c|c|c|c|c|}
\hline \multicolumn{2}{|c|}{ total compositions } & \multicolumn{2}{|c|}{ top phase } & \multicolumn{2}{|c|}{ bottom phase } & \multirow[b]{2}{*}{ slope } & \multirow[b]{2}{*}{$\sigma$} & \multirow[b]{2}{*}{ medium } \\
\hline $100 w_{1}$ & $100 w_{2}$ & $100 w_{1}$ & $100 w_{2}$ & $100 w_{1}$ & $100 w_{2}$ & & & \\
\hline 4.3 & 9.3 & 6.2 & 6.0 & 2.9 & 11.7 & -0.58 & 0.0021 & \\
\hline 4.8 & 9.9 & 8.1 & 3.8 & 2.0 & 15.0 & -0.54 & 0.0023 & -0.55 \\
\hline 5.3 & 10.5 & 9.3 & 3.0 & 1.5 & 17.5 & -0.54 & 0.0027 & \pm 0.02 \\
\hline 6.0 & 11.9 & 11.1 & 2.4 & 1.3 & 20.8 & 0.53 & 0.0025 & \\
\hline plait point & & 8.00 & 4.10 & & & & & \\
\hline
\end{tabular}

and above), which makes it a flexible and promising phase system for separation of biomaterials. Because of this, this system has been ${ }^{17,18}$ and will be used in the separation of proteins at increasing attention.

Ucon + PVA 10000 + Water and Ucon + PES $100+$ Water. The phase diagram data for the U con + PVA 10000 + water system at $22{ }^{\circ} \mathrm{C}$ were presented in Table 2 and Figure 4. The standard deviation for the slope of each tie line is lower than 0.04 .

The phase diagram of the Ucon + PES + water system at $22{ }^{\circ} \mathrm{C}$ was shown in Table 3 and Figure 5. The standard deviations for the tieline slopes were found to be 0.03 . Similar phase diagrams (see Figure 5) were obtained in the literature, ${ }^{17,23}$ using either Ucon or Breox 50A1000 to construct ATPS at $20^{\circ} \mathrm{C}$ with PES 100. Breox 50A1000 is

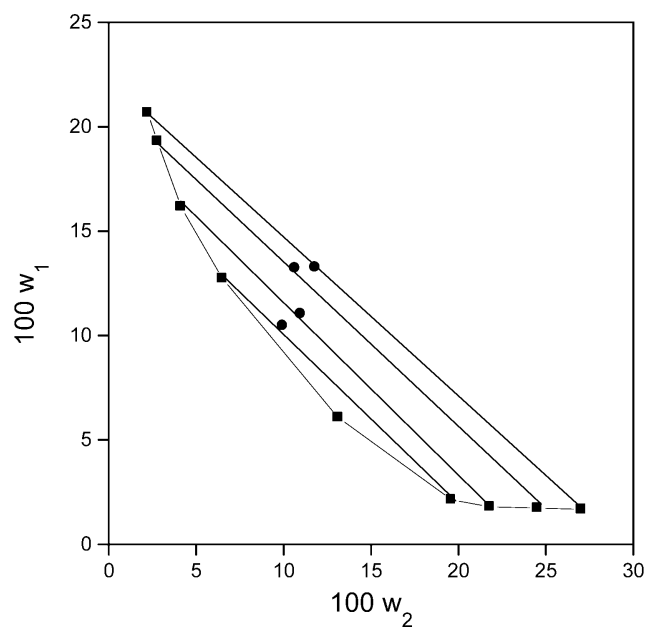

Figure 4. Phase diagram of the Ucon + PVA $10000+$ water

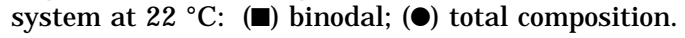

another $50 \%$ EO-50\% PO copolymer that is very similar to $\mathrm{U}$ con but has a different source. Some difference in the compositions of the bottom phases was found between the phase diagram in this work and those found in the literature. The data ${ }^{17,23}$ have smaller amounts of the EOPO copolymers in the bottom phases. This might be due to the temperature differences between these phase diagrams and the experimental errors associated with their determination.

Both U con + PVA 10000 + water and Ucon + PES 100 + water systems are very similar to the poly(ethylene glycol) + PES100 + water system, ${ }^{11}$ where high polymer concentrations are required to form the two phases.

PEG $\mathbf{8 0 0 0}+$ PVA $\mathbf{1 0 0 0 0}+$ Water. The liquid-liquid equilibrium data of the PEG8000 + PVA 10000 + water

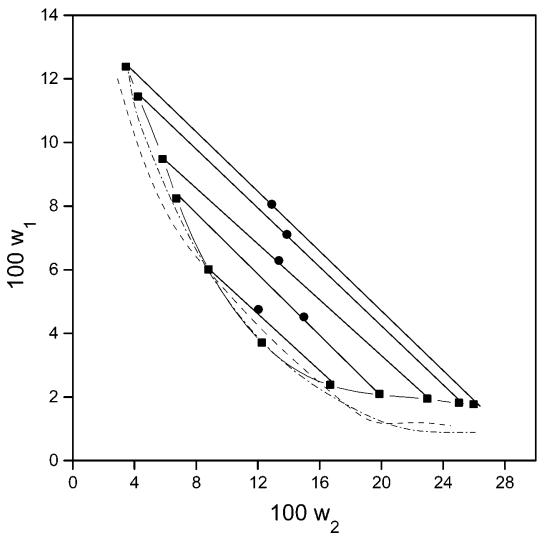

Figure 5. Phase diagram of the U con $50-\mathrm{HB}-5100+$ Reppal PES 100 + water system at $22^{\circ} \mathrm{C}$ : ( $\left.\mathbf{(}\right)$ binodal; (๑) total composition; (- - -) binodal for the U con 50-HB-5100 + Reppal PES $100+$ water system at $20^{\circ} \mathrm{C} ;{ }^{17}$ (- - -) binodal for the Breox PUR A1000 + Reppal PES 100 + water system at $20^{\circ} \mathrm{C} .{ }^{23}$ 


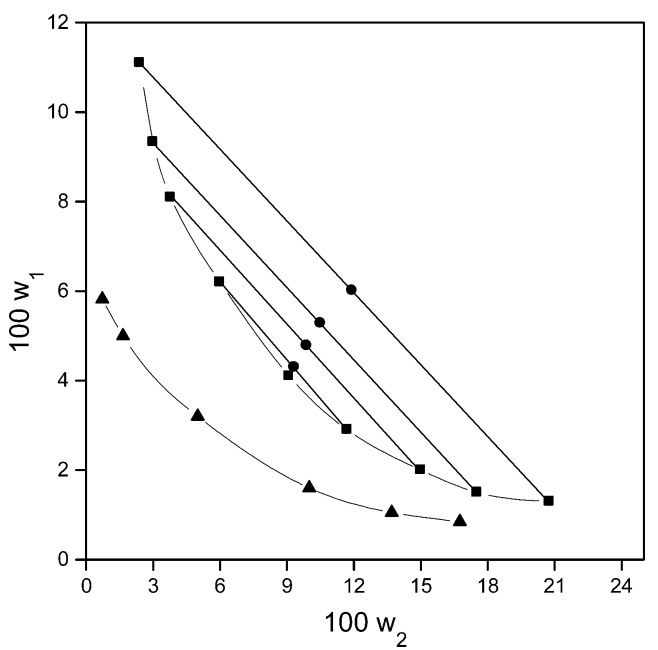

Figure 6. Phase diagram of the PEG + PVA $10000+$ water system at $22{ }^{\circ} \mathrm{C}$ : (回) binodal; (๑) total composition for the PEG 8000 system; ( $\mathbf{\Lambda}$ ) binodal for the PEG 20000 system. $^{24}$

system were given in Table 4 and Figure 6 . The standard deviation for the slope of each tie line was about 0.0025 . In the same figure, the binodal curve for the PEG $20000+$ PVA 10000 + water system was also shown for comparison. ${ }^{24}$ Since PEG 8000 has a smaller molecular weight than PEG 20000, the formation of two phases occurs at higher polymer concentrations for the PEG 8000 + PVA 10000 + water system. This system has been successfully utilized for the purification of endo-polygalacturonase in our laboratory. ${ }^{21}$

\section{Conclusions}

The phase diagrams of $\mathrm{U}$ con $+\left(\mathrm{NH}_{4}\right)_{2} \mathrm{SO}_{4}+$ water, $\mathrm{U}$ con + PVA 10000 + water, Ucon + PES100 + water, and PEG8000 + PVA 10000 + water systems were determined. It has been shown that the thermoseparating polymer is a good alternative to be used as one of the phase-forming species in aqueous two-phase systems. F or the U con + salt + water system, the phase formation is temperature dependent and the phases can be inversed by increasing the temperature to change the densities of the phases. For the formation of two phases, this system also requires much lower amounts of polymer and salt than conventional systems. These characteristics make U con $+\left(\mathrm{NH}_{4}\right)_{2} \mathrm{SO}_{4}+$ water ATPS a promising, versatile, and attractive system in the field of bioseparation. Although PVA 10000 is not suitable for recycling on the industrial scale, the presence of Ucon + PVA 10000 + water and PEG + PVA 10000 + water systems can broaden aqueous two-phase systems and the applications in bioseparation .

\section{Literature Cited}

(1) Beijernick, M. W. Original mitteilung uber eine eigentumlichkeit der loslichen starke. Centrabl. Bakteriologie, Parasitenkunde Infektioskrankheiten 1896, 22, 699-701.

(2) Albertsson, P. A. Chromatography and partition of cells and cells fragments. Nature 1956, 177, 771-774.

(3) Kula, M.-R.; Kroner, K. H.; Hustedt, H. Purification of enzymes by liquid-liquid extraction. Adv. Biochem. Eng. 1982, 24, 73118.

(4) Veide, A.; Leindbäck, T.; Enfors, S.-O. Continuous extraction of $\beta$-D-galactosidase from Escherichia coli in an aqueous two-phase system: effects of biomass concentration on partitioning and mass transfer. Enzyme Microb. Technol. 1984, 6, 325-330.

(5) Wu, Y.-T.; Pereira, M.; Venâncio, A.; Teixeira, J . Recovery of endopolygalacturonase using poly(ethylene glycol)-salt aqueous twophase extraction with polymer recycling. Bioseparation 2000, 9, 247-254.

(6) J ohansson, H.-O.; Karlström, G.; Tjerneld, F.; Haynes, C. A. Driving forces for phase separation and partitioning in aqueous two-phase systems. J . Chromatogr., B 1998, 711, 3-17.

(7) J ohansson, H.-O.; Karlström, G.; Mattiasson, B.; Tjerneld, F. Effects of hydrophobocity and counterions on the partitioning of amino acids in thermoseparating U con-water two phase systems. Bioseparation 1995, 5, 269-279.

(8) J ohansson, H.-O.; Persson, J .; Tjerneld, F. Thermoseparated water/polymer system: a novel one-polymer aqueous two-phase system. Biotechnol. Bioeng. 1999, 66, 247-257.

(9) Albertsson, P. A. Partitioning of cell particles and macromolecules, 3rd ed.; J ohn Wiley and Sons: New York, 1986.

(10) Walter, H., J ohansson, G., Eds. Methods in Enzymol ogy; Academic Press: London, 1994.

(11) Zaslavsky, B. Y. Aqueous two-phase partitioning: physical chemistry and bioanalytical applications; Marcel Dekker: New York, 1995.

(12) Kroner, K. H.; Hustedt, H.; Kula, M.-R. Evaluation of crude dextran as phase forming polymer for the extraction of enzymes in aqueous two-phase systems in large scale. Bi otechnol. Bi oeng. 1982, 24, 1015-1045.

(13) Tjerneld, F.; Berner, S.; Cajarville, A.; J ohansson, G. New aqueous two-phase systems based on hydroxypropyl starch useful in enzyme purification. Enzyme Microb. Technol. 1986, 8, 417-423.

(14) Sturesson, S.; Tjerneld, F.; J ohansson, G. Partitioning of macromolecules and cell particles in aqueous two-phase systems based on hydroxypropyl starch and poly(ethylene glycol). Appl. Biochem. Biotechnol. 1990, 26, 281-295.

(15) Venâncio, A.; Teixeira, J. A.; Mota, M. Evaluation of crude hydroxypropyl starch as a bioseparation aqueous-phase forming polymer. Biotechnol. Prog. 1993, 9, 635-639.

(16) Alred, P. A.; Tjerneld, F.; Koslawsky, A.; Harris, M. J . Synthesis of dye conjugates of ethylene oxide-propylene oxide copolymers and application in temperature-induced phase partitioning. Bioseparation 1992, 2, 363-373.

(17) Persson, J .; Nyström, L.; Ageland, H.; Tjerneld, F. Purification of recombinant apolipoprotein A-1 Milano expressed in Escherichia coli using aqueous two-phase extraction followed by temperature induced phase separation. J . Chromatogr., B 1998, 711, 97-109.

(18) Pereira, M.; Wu, Y.-T.; Venâncio, A.; Teixeira, J. Aqueous TwoPhase Extraction Using Thermoseparating Polymer: A New System for the Separation of Endo-polygalacturonase. Biochem. Eng. J. 2003, 15, 131-138.

(19) Yurow, H. W.; Master, I. Novel colour reactions for ammonium ion in acidic solution. Talanta 1978, 25 (7), 423-424.

(20) Lei, Y.; Zheng, Q.; Xu, M. Determination of nitrogen in ammonium by potentiometry. Chongqing Daxue Xuebao 1986, 9 (4), 134-40 (Chinese).

(21) Wu, Y.-T.; Pereira, M.; Venâncio, A.; Teixeira, J . A. Separation of Endo-Polygalacturonase Using Aqueous Two-Phase Partitioning. J . Chromatogr., A 2001, 929 (1-2), 23-29.

(22) Li, W.; Lin, D.-Q.; Zhu, Z.-Q. Measurement of water activities and prediction of liquid-liquid equulibria for water + ethylene oxidepropilene oxide random copolymer + ammonium sulfate systems. Fluid Phase Equilib. 2000, 93, 15-26.

(23) Persson, J.; Nyström, L.; Ageland, H.; Tjerneld, F. Purification of recombinant and human apolipoprotein A-1 using surfactant micelles in aqueous two-phase systems: recycling of thermoseparating polymer and surfactant with temperature-induced phase separation. Biotechnol. Bioeng. 1999, 65, 371-381.

(24) Fisher, D.; Sutherland, I. A. Separations using aqueous phase systems: applications in cell biology and biotechnology; Plenum: New York, 1989.

Received for review February 21, 2003. Accepted September 24, 2003. M.P. and Y.-T.W. were financially supported by the Praxis XXI program of FCT (Fundação para a Ciência e Tecnologia) of Portugal. P.M. was financially supported by project POCTI/EQU/ $33185 / 99$. This work was from project CEC (INCO-DC) with the contract number ERB IC18 CT97 0182

J E034038D 